\title{
AIKUISKOULUTTAJIEN KOULUTUS MURROSVAIHEESSA
}

\begin{abstract}
"Aikuiskasvattajien koulutus kaipaa selvittelyä", kirjoitin neljä vuotta sitten tällä paikalla. Kokonaisselvittelyn tarve on nyt entistä ilmaisempi, vaikka tällä välin on aikuiskouluttajien koulutuksesta tehty monenkinlaisia suunnitelmia ja osa niistä on edennyt hyvää vauhtia toteuttamisen asteelle. Lehtemme tämä numero sisältää tuoretta tietoa siitä, mitä tällä alalla on parhaillaan tekeillä. Esittelemättä jäävät tässä vaiheessa mm. ammattikasvatushallituksen asettaman työryhmän suunnitelmat. Niihin on syytä palata kun nyt luonnosvaiheeseen saatu muistio on julkistettu.
\end{abstract}

Aikuiskouluttajien kouluttamisen suunnittelu ja järjestäminen on parina viime vuonna keskittynyt ammatillisen koulutuksen alueelle. Syynä tähän ovat olleet ne akuutit tarpeet, joita tämän alueen ekspansio yleensä ja erityisesti ammatillisten oppilaitosten tehtävien laajentuminen ovat synnyttäneet. Ammatillisiksi opettajakorkeakouluiksi pikavauhtia muuttuneet opettajaopistot ovat puolestaan saaneet keskeisen aseman uusien suunnitelmien toteuttajina. Ilmeisen perusteltua onkin, että samat oppilaitokset, jotka tähänkin asti ovat kouluttaneet ammattioppilaitosten opettajia, nyt niiden tehtävien laajentuessa vastaavasti suuntautuvat myös aikuisopetukseen erikoistavaan koulutukseen. Sama pätee ainakin huomattavalta osalta ammattikurssikeskusten (ammatillisten aikuiskoulutuskeskusten) opettajankoulutukseen.

Mainitut suunnitelmat rajoittuvat kuitenkin vain yhteen aikuiskoulutuksen lohkoon eivätkä ne sovellu yleismalliksi siihen tapaan kuin joistakin valtion opetushallinnon suunnitteluasiakirjoista voisi päätellä. Ammatillisenkin aikuiskoulutuksen omassa piirissä henkilöstökoulutuksen kouluttajilla on omat erityiset toimintakehyksensä. Sikäli kuin henkilöstökoulutuksessa yleistyy toimintatapa, jossa koulutustehtävät sisältyvät kiinteänä osana työorganisaation yleiseen kehittämiseen, muuttuu kouluttajan toimenkuva ja pätevöitymistapa vastaavasti (ks. Vennan ja Rautiaisen kirjoitusta).

Vapaa sivistystyö, avoin korkeakoulu, aikuislukiot jne asettavat aikuiskouluttajille toimintajärjestelmiensä mukaisia erityisvaatimuksia. En käsittele tässä niitä enempää kuin kouluttajakategoriainkaan mukaan vaihtelevia koulutustarpeita (opettajat, hallinto- ja suunnittelutehtävissä toimivat, sivutoimiset opettajat). Tarkastelen sen sijaan, millä tavoin em. ammatilliseen aikuiskoulutukseen keskittyneissä suunnitelmissa on käsitetty kouluttajan tarvitsemat pedagogiset tai andragogiset valmiudet.

Niin valtionopetushallinnon viimeaikaiset suunnitelmat kuin esimerkiksi ammatillisten opettajakorkeakoulujen ohjelmat (Helakorven artikkeli) osoittavat, että aikuisten kouluttamisen on katsottu asettavan kouluttajille ainakin jossakin määrin toisenlaisia ammattitaidon vaatimuksia kuin nuorten kouluopetuksen. Käsitykset siitä, miten tämän tulisi ilmetä koulutusohjelmien tavoitteissa ja sisällöissä, ovat toistaiseksi aika tavalla 
jäsentymättömiä ja pitkälti arkiajatteluun perustuvia. Yksinkertaisimmillaan argumentaatio noudattaa edelleen vanhaa tuttua logiikkaa: koska aikuisopetuksessa käytetän samoja metodeja kuin nuorison kouluopetuksessa, ei kouluttajien koulutuksessa tarvitse olla merkittävää eroa. Yhtään sen lähemmäksi ei aikuisopetuksen erityisluonnetta päästä, kun etsimällä etsitään aikuisopetuksen "omia" menetelmiä (erään muistioluonnoksen mukaan niitä voisivat olla case-harjoitukset, roolipelit ja TAO). Pitemmälle on päästy, kun puhutaan oppijain aikuisuuden ja elämänolosuhteiden sekä työkokemuksen huomioon ottamisesta.

Erityisen tärkeäksi aikuiskouluttajan taidoksi on opetusministeriön muistioissa ja kouluttajaorganisaatioiden suunnitelmissa nostettu monimuoto-opetuksen hallinta. On kyllä totta että ohjatun itseopiskelun yhdistämistä lähiopetuksen muotoihin kannattaisi käyttää tähänastista huomattavasti enemmän - ja taitavammin. Alkuinnostuksessa on kuitenkin jäänyt yleensä huomaamatta, että ohjattu itseopiskelu asettaa oppijalle huomattavasti suuremmat oppimistaitojen ja motivaation vaatimukset kuin muut opintomuodot. Nopeasti kehittyvät viestintäteknologiset välineet avaavat puolestaan etäopetukselle uusia hienoja mahdollisuuksia, mutta niiden uutuushakuinen käyttöönotto näyttää helposti saavan suoranaisia välinefetisismin piirteitä - sen jota Tiuran Santeri käytti hyväksi markkinoidessaan yhden, kahden ja kolmen ristin ällätikkuja.

Neljän vuoden takaisessa pääkirjoituksessa kiinnitin huomiota siihen, että yliopistojen kasvatustieteelliset laitokset ilmoittivat kasvatustieteen (hallinnon ja suunnittelun) koulutusohjelmiensa tuottavan valmiuksia aikuiskouluttajan tehtäviin, mutta että niiden opetussuunnitelmissa käsiteltiin kovin vähän aikuiskasvatuksen erityiskysymyksiä. Samoin on laita vieläkin; "jakamattoman kasvatustieteen" uskotaan riittävän myös aikuiskouluttajien tarpeeseen.

Samantapainen käsitys "yleispedagogisten" opintojen kattavuudesta on ominaista edellä puheena olleille uusille kouluttajaohjelmille. Näyttääpä tämä ajattelutapa ohjanneen kansanopistojen ja kansalaisopistojenkin harjoitteluohjelman uudistusta (Saari-Musakan katsaus).

On kaiketi pidettävä aikuiskouluttajien koulutuksen murrosvaiheeseen kuuluvana, että nyt kehitellään koulutusohjelmia, joissa aikuiskasvatustieteellä ei ole suurtakaan sijaa. Rohkenen kuitenkin ennustaa, että kiinnostus aikuiskasvatukseen teoreettisiin perusteisiin kasvaa sitä mukaan, kun koulutusohjelmista saadaan käytännön kokemusta ja niiden laadullinen kehittäminen etenee. Toisaalta on merkille pantavaa, että perinteisen pedagogisen kasvatustieteen ajattelutavat ja sisältörakenteet ovat muuttumassa jatkuvan kasvatuksen avarampien perspektiivien suuntaan. 